OPEN ACCESS

Edited by:

Patrick Brown,

University of California, Davis,

United States

Reviewed by:

Fabio Francesco Nocito,

University of Milan, Italy

Graham Henry Lyons,

The University of Adelaide, Australia

${ }^{*}$ Correspondence:

Ismail Cakmak

cakmak@sabanciuniv.edu

Specialty section:

This article was submitted to Plant Nutrition,

a section of the journal

Frontiers in Plant Science

Received: 31 July 2020 Accepted: 15 September 2020 Published: 13 November 2020

Citation:

Prom-u-thai C, Rashid A, Ram H, Zou C, Guilherme LRG, Corguinha APB, Guo S, Kaur $C$,

Naeem A, Yamuangmorn $S$, Ashraf MY, Sohu VS, Zhang Y,

Martins FAD, Jumrus S, Tutus $Y$,

Yazici MA and Cakmak I (2020) Simultaneous Biofortification of Rice With Zinc, Iodine, Iron and Selenium Through Foliar Treatment of a Micronutrient Cocktail in Five

Countries.

Front. Plant Sci. 11:589835. doi: 10.3389/fpls.2020.589835

\section{Simultaneous Biofortification of Rice With Zinc, lodine, Iron and Selenium Through Foliar Treatment of a Micronutrient Cocktail in Five Countries}

Chanakan Prom-u-thai' ${ }^{1}$, Abdul Rashid ${ }^{2}$, Hari Ram ${ }^{3}$, Chunqin Zou', Luiz Roberto Guimaraes Guilherme ${ }^{5}$, Ana Paula Branco Corguinha ${ }^{5}$, Shiwei Guo ${ }^{6}$, Charanjeet Kaur ${ }^{7}$, Asif Naeem ${ }^{8}$, Supapohn Yamuangmorn ${ }^{1}$, Muhammad Yasin Ashraf ${ }^{8}$, Virinder Singh Sohu ${ }^{3}$, Yueqiang Zhang ${ }^{9}$, Fábio Aurélio Dias Martins ${ }^{10}$, Suchada Jumrus ${ }^{1}$, Yusuf Tutus ${ }^{11}$, Mustafa Atilla Yazici'11 and Ismail Cakmak ${ }^{11 *}$

\footnotetext{
${ }^{1}$ Agronomy Division, Department of Plant and Soil Sciences, Faculty of Agriculture, Chiang Mai University, Chiang Mai, Thailand, ${ }^{2}$ Pakistan Academy of Sciences, Islamabad, Pakistan, ${ }^{3}$ Department of Plant Breeding \& Genetics, Punjab Agricultural University, Ludhiana, India, ${ }^{4}$ Center for Resources, Environment and Food Security, China Agricultural University, Beijing, China, ${ }^{5}$ Department of Soil Science, Federal University of Lavras, Lavras, Brazil, ${ }^{6}$ College of Resources and Environment, Nanjing Agricultural University, Nanjing, China, ${ }^{\top}$ Punjab Agricultural University Regional Research Station, Gurdaspur, India, ${ }^{8}$ Soil and Environmental Sciences Division, Nuclear Institute for Agriculture and Biology, Faisalabad, Pakistan, ${ }^{9}$ College of Resources and Environment, Southwest University, Chongqing, China, ${ }^{10}$ Minas Gerais State Agricultural Research Agency, EPAMIG Sul, Campus Universitário UFLA, Lavras, Brazil, ${ }^{11}$ Faculty of Engineering and Natural Sciences, Sabancı University, Istanbul, Turkey
}

Widespread malnutrition of zinc (Zn), iodine (I), iron (Fe) and selenium (Se), known as hidden hunger, represents a predominant cause of several health complications in human populations where rice (Oryza sativa L.) is the major staple food. Therefore, increasing concentrations of these micronutrients in rice grain represents a sustainable solution to hidden hunger. This study aimed at enhancing concentration of Zn, I, Fe and Se in rice grains by agronomic biofortification. We evaluated effects of foliar application of $\mathrm{Zn}, \mathrm{I}, \mathrm{Fe}$ and Se on grain yield and grain concentration of these micronutrients in rice grown at 21 field sites during 2015 to 2017 in Brazil, China, India, Pakistan and Thailand. Experimental treatments were: (i) local control (LC); (ii) foliar Zn; (iii) foliar I; and (iv) foliar micronutrient cocktail (i.e., Zn + I + Fe + Se). Foliar-applied Zn, I, Fe or Se did not affect rice grain yield. However, brown rice $\mathrm{Zn}$ increased with foliar $\mathrm{Zn}$ and micronutrient cocktail treatments at all except three field sites. On average, brown rice $\mathrm{Zn}$ increased from $21.4 \mathrm{mg} \mathrm{kg}^{-1}$ to $28.1 \mathrm{mg} \mathrm{kg}^{-1}$ with the application of $\mathrm{Zn}$ alone and to $26.8 \mathrm{mg} \mathrm{kg}^{-1}$ with the micronutrient cocktail solution. Brown rice I showed particular enhancements and increased from $11 \mu \mathrm{g} \mathrm{kg}^{-1}$ to $204 \mu \mathrm{g} \mathrm{kg}^{-1}$ with the application of I alone and to $181 \mu \mathrm{g} \mathrm{kg}^{-1}$ with the cocktail. Grain Se also responded very positively to foliar spray of micronutrients and increased from 95 to $380 \mu \mathrm{g} \mathrm{kg}^{-1}$. By contrast, grain Fe was increased by the same cocktail spray at only two sites. There was no relationship between soil extractable concentrations of these micronutrients with 
their grain concentrations. The results demonstrate that irrespective of the rice cultivars used and the diverse soil conditions existing in five major rice-producing countries, the foliar application of the micronutrient cocktail solution was highly effective in increasing grain Zn, I and Se. Adoption of this agronomic practice in the target countries would contribute significantly to the daily micronutrient intake and alleviation of micronutrient malnutrition in human populations.

Keywords: rice, zinc, iodine, iron, selenium

\section{INTRODUCTION}

Globally, an estimated 2 billion people suffer from micronutrient malnutrition (also known as hidden hunger), especially in the developing world. Particular micronutrient deficiencies include $\mathrm{Fe}, \mathrm{Zn}$, Se and I which result in severe health complications (Bailey et al., 2015; Harding et al., 2018) as well as significant economic losses (Gödecke et al., 2018). Due to their high requirements, infants, preschool children, and women of reproductive age are more vulnerable to micronutrient malnutrition.

Iron deficiency has been suggested to be the most common micronutrient disorder in human populations, and is often associated with anemia (Bailey et al., 2015). The most prevalent form of anemia is the Fe deficiency anemia which affects over 1 billion people worldwide (Camaschella, 2019). Zinc malnutrition has been found to be responsible for the death of 116,000 children under five years of age, mainly due to enhanced infectious diseases such as diarrhea and pneumonia (Black et al., 2013). Zinc has strong antiviral and antibacterial effects in the human body and is involved in improving immune function and immune response against various viruses, including corona virus (Read et al., 2019; Skalny et al., 2020). Similarly, Se is also required for optimizing the immune system against viral attacks and is required in prevention of various types of cancer in human body and can lower risk of some cancers (Steinbrenner et al., 2015). A large proportion of the world population is known to be at risk of Se malnutrition due to inadequate dietary Se intake (Jones et al., 2017).

Despite the use of iodized salt since decades, human I deficiency has been reported to be still prevalent in a number of countries. An estimated 2 billion people are at risk of I deficiency (Zimmermann and Andersson, 2012; Pearce et al., 2013). Even, some reports indicate that I deficiency is a re-emerging public health problem (Lazarus, 2015; Panth et al., 2019). The welldocumented role of I in the human body is related to biosynthesis of thyroid hormones which are important in brain function and mental development (Pearce et al., 2016).

Low availability of soil micronutrients to crop plants and consequent inadequate dietary intake of micronutrients have been discussed as the root cause for the high incidence of micronutrient deficiencies in humans (Welch et al., 2013). According to Welch et al. (2013) crop production systems have never been designed with the aim to improve human nutrition and health which is a further particular reason which partly explains the widespread occurrence of hidden hunger in the world. Therefore, crop production systems should include nutrition-sensitive approaches and be aligned with the production of micronutrient-enriched (biofortified) staple foods for the target populations (Bouis and Saltzman, 2017; Cakmak and Kutman, 2018; Jha and Warkentin, 2020). Most of the staple foods are inherently very low in micronutrients and cannot meet the recommended daily intake of micronutrients (Cakmak, 2008; Andersson et al., 2017; Bouis and Saltzman, 2017), especially rice which is inherently low in micronutrients and is then processed extensively before consumption such as polishing, steaming and parboiling (Balbinoti et al., 2018; Ito and Lacerda, 2019). Today, increasing nutritional value and composition of rice, especially regarding micronutrients is, therefore, a growing challenge.

Among the approaches for enrichment (i.e., biofortification) of micronutrient in staple foods, genetic (i.e., plant breeding) and agronomic (i.e., use of fertilizers) approaches are used widely. After long-term successful efforts, the International HarvestPlus program has developed and released new $\mathrm{Zn}$ - or $\mathrm{Fe}$-biofortified wheat and rice varieties containing additional $\mathrm{Zn}$ or Fe, at about $10 \mathrm{mg}$ per $\mathrm{kg}$ grain (Andersson et al., 2017; HarvestPlus, 2020). Also, multi-country field trials established in the framework of the HarvestZinc project have demonstrated that agronomic biofortification, a fertilizer-based approach, is highly effective in improving grain concentrations of the targeted micronutrients in food crops as shown in wheat, rice, maize and bean for Zn, Se and I (Phattarakul et al., 2012; Zou et al., 2012; Mao et al., 2014; Ram et al., 2016; Cakmak et al., 2017). The impact of the fertilizer-use strategy on grain micronutrient concentration was much more pronounced for foliar in case of the use of foliar sprays, compared with soil applications, for example, $\mathrm{Zn}$ in rice plants grown under field conditions (Wissuwa et al., 2007; Phattarakul et al., 2012; Saha et al., 2017). Higher agronomic effectiveness of foliar application over soil application in boosting grain $\mathrm{Zn}$ has been also shown for several other crop species (Wang et al., 2012; Zou et al., 2012; Mao et al., 2014; Cakmak and Kutman, 2018).

The contribution of root absorption and root-to-grain transportation of $\mathrm{Zn}$ and $\mathrm{Fe}$ during the grain filling stage is minimal under field conditions compared to the greenhouse conditions with always high amount of available micronutrients and optimal water (Waters et al., 2009; Kutman et al., 2012; Sperotto et al., 2013; Cakmak and Kutman, 2018). This indicates that mobilization and retranslocation of the already deposited micronutrient reserves within the vegetative tissues to the grains are the key constraints affecting grain accumulation of 
micronutrients under field conditions. Therefore, maintaining a high pool of micronutrients in the vegetative tissue just before and/or during the grain filling stage, which can be attained with foliar application of micronutrients during grain filling stage, is of great importance and relevance for increasing grain micronutrients (Cakmak and Kutman, 2018). As shown for rice, plant genotypes differ in their genetic capacity to mobilize and translocate $\mathrm{Zn}$ from vegetative tissues to grains which needs to be considered in micronutrient biofortification studies (Impa et al., 2013; Johnson-Beebout et al., 2016).

In the present study, we aimed to investigate the foliar applications of $\mathrm{Zn}, \mathrm{I}, \mathrm{Fe}$ and Se alone or together in a cocktail solution on the grain concentrations of these micronutrients in rice grown under different soil and crop management conditions of five major rice growing countries over two years by using seven different rice cultivars. Indeed, there are many publications about the effect of soil and/or foliar applications of micronutrients, usually alone or 2 combined elements, on grain concentration of micronutrients in food crops (Cakmak, 2008; Duffner et al., 2014; Dimkpa and Bindraban, 2016; de Valença et al., 2017; Lyons, 2018). To the best of our knowledge, this is the first study investigating the effect of a cocktail micronutrient solution on grain concentrations of $\mathrm{Zn}, \mathrm{I}, \mathrm{Fe}$ and Se under diverse soil and environmental conditions in five rice growing countries.

\section{MATERIALS AND METHODS}

\section{Establishment of Field Experiment}

A field experiment on rice was conducted over two cropping seasons in 2015 to 2017 at a total of 21 field sites of five countries, i.e., Brazil, China, India, Pakistan and Thailand. Except for Brazil, where rice was cultivated under upland conditions, in all other locations rice was grown under flooded conditions with 10 to $20 \mathrm{~cm}$ standing water above the soil surface for most of the growing season. The rice cultivars grown at various field sites were commonly cultivated in the respective countries (Table 1).

TABLE 1 | Location and other variables of the foliar fertilizer experiment in rice grown in wetland conditions conducted at 21 field sites of five countries during 2015-2017.

\begin{tabular}{llll}
\hline Country & Year & Field location & Rice cultivar \\
\hline Brazil & 2016 & Lambari, and Patos de Minas & BRSMG Caravera \\
& 2017 & Lambari, and Patos de Minas & BRSMG Caravera \\
China & 2015 & Jiangsu & Zhengdao11 \\
& 2016 & Chongqing & Xiyou19 \\
India & 2015 & Ludhiana, and Gurdaspur & PR 124 \\
& 2016 & Ludhiana, and Gurdaspur & PR 121 \\
Pakistan & 2016 & Gujranwala-I, Sheikhupura-I, & Super Basmati \\
& 2017 & and Sialkot & Sujranwala-II, Sheikhupura-II, \\
& 2015 & and Sahiwal & CMU, and Maehia \\
Thailand & 2016 & CMU, and Maehia & SPT1 \\
& & SPT1
\end{tabular}

Initial soil characteristics of the field locations, including DTPAextractable soil $\mathrm{Zn}$ and Fe measured by Lindsay and Norvell (1978), I determined by Cakmak et al. (2017) and Se measured by Dhillon et al. (2005) are presented in Table 2. The basal fertilizers applied according to local practices of the countries are given in Table 3 and were accomplished before transplanting the crop (except for Brazil, were rice seeds were used instead of seedlings). The given rates of $\mathrm{N}$ fertilizer were split-applied and based on respective country's recommendations as detailed in Table 3.

\section{Experimental Design, Foliar Applications and Crop Harvesting}

The experiment comprised four treatments: i) local control (i.e., basal N, P, K fertilizers only, no micronutrient applied); ii) local control + foliar application of $\mathrm{Zn}\left(0.5 \% \mathrm{ZnSO}_{4} \cdot 7 \mathrm{H}_{2} \mathrm{O}\right.$ in spray solution); iii) local control + foliar application of $\mathrm{I}\left(0.05 \% \mathrm{KIO}_{3}\right.$ in spray solution); and iv) local control + simultaneous foliar spray of micronutrients ( $\mathrm{Zn}, \mathrm{I}, \mathrm{Fe}$ and $\mathrm{Se}$ ) in a cocktail solution containing $0.5 \% \mathrm{ZnSO}_{4} \cdot 7 \mathrm{H}_{2} \mathrm{O}+0.05 \% \mathrm{KIO}_{3}+0.02 \%$ Fe-EDTA $+0.001 \% \mathrm{Na}_{2} \mathrm{SeO}_{4}$. The field experiment was laid out in a randomized complete block design with four replications. The foliar solution of each treatment, varying between 500 to $800 \mathrm{~L}$ $\mathrm{ha}^{-1}$, was applied twice, i.e., at the panicle initiation (about one week prior to heading) and the early grain milk stages. The foliar treatments were applied at late afternoon time until the solution started to run-off from the leaves as described by Cakmak et al. (2010). At grain maturity, rice grain yield was recorded from 6 to $10 \mathrm{~m}^{2}$ central area of each plot.

\section{Chemical Analyses}

Subsamples of brown rice (whole caryopsis, without husk) from each plot were secured for analysis of Zn, I, Fe and Se. Brown rice samples were rinsed and washed with distilled de-ionized (DDI) water and dried first with tissue papers and then at about $45{ }^{\circ} \mathrm{C}$ in a forced-draft oven to constant weight. Dried brown rice grains were digested in $\mathrm{HNO}_{3}-\mathrm{H}_{2} \mathrm{O}_{2}$ mixture in a microwave accelerated reaction system (CEM Corp., United States) for the determination of $\mathrm{Zn}, \mathrm{Fe}$ and Se. For I analysis, brown rice samples were extracted in TMAH at $90{ }^{\circ} \mathrm{C}$ using a closed-vessel microwave reaction system (CEM Corp., United States) as described earlier by Zia et al. (2015) and Cakmak et al. (2017). Zinc and Fe concentrations in the digested solutions were measured by inductively coupled plasma optical emission spectroscopy (ICPOES), and I and Se concentrations by inductively coupled plasma mass spectrometry (ICP-MS). Measurement of mineral nutrients was checked by using certified standard reference materials obtained from the National Institute of Standards and Technology (Gaithersburg, MD, United States).

\section{Statistical Analysis}

The significance of the effects of different foliar treatments on the dependent variables was determined using one-factor ANOVA at 0.05 probability level of least significant difference (LSD) test using SAS software (SAS 8.0, United States). For overall effectiveness, the data sets across locations and years were 
TABLE 2 | Initial soil characteristics of 21 experimental field sites in 14 locations of five countries.

\begin{tabular}{|c|c|c|c|c|c|c|c|c|}
\hline Country & Location & $\mathrm{pH}$ & $\begin{array}{r}\text { DTPA Zn } \\
\text { (m }\end{array}$ & $\begin{array}{l}\text { DTPA Fe } \\
-1 \text { ) }\end{array}$ & $\begin{array}{c}\text { Extractable } P \\
\left(\mathrm{mg} \mathrm{kg}^{-1}\right)\end{array}$ & $\begin{array}{c}\text { Extractable } \mathrm{K} \\
\qquad\left(\mathrm{mg} \mathrm{kg}^{-1}\right)\end{array}$ & $\begin{array}{l}\text { TMAH extractable I } \\
\left(\mathrm{mg} \mathrm{kg}^{-1}\right)\end{array}$ & $\begin{array}{l}\text { Extractable Se } \\
\qquad\left(\mu \mathrm{g} \mathrm{kg}^{-1}\right)\end{array}$ \\
\hline Brazil & Lambari & 5.5 & 1.1 & 176 & 39 & 54 & 2.9 & 12.7 \\
\hline \multirow[t]{2}{*}{ China } & Jiangsu & 7.5 & 1.2 & 115 & 8.4 & 80 & 0.7 & 10.8 \\
\hline & Chongqing & 7.5 & 0.6 & & 10.1 & 138 & 0.9 & 21.7 \\
\hline India & Ludhiana & 7.7 & 3.7 & 84 & 20 & 178 & 0.9 & 15.1 \\
\hline \multirow[t]{6}{*}{ Pakistan } & Gujranwala-I & 8.2 & 1.5 & 33 & 4 & 41 & 0.2 & 26.4 \\
\hline & Sheikhupura-I & 8.2 & 2.0 & 49 & 18 & 77 & 0.6 & 12.1 \\
\hline & Sialkot & 8.1 & 2.1 & 113 & 26 & 77 & 0.9 & 14.0 \\
\hline & Gujranwala-II & 8.1 & 0.6 & 14 & 8 & 51 & 0.5 & 8.6 \\
\hline & Sheikhupura-II & 8.3 & 1.7 & 22 & 26 & 77 & 1.0 & 20.2 \\
\hline & Sahiwal & 8.0 & 0.9 & 17 & 30 & 80 & 0.2 & 8.6 \\
\hline
\end{tabular}

Extractable I was determined by Tetra methyl ammonium hydroxide (TMAH) method by Zia et al. (2015) and Cakmak et al. (2017), extractable Se was determined by Dhillon et al. (2005), extractable $\mathrm{Zn}$ and Fe were determined by DTPA, extractable P by Bray-ll and extractable $\mathrm{K}_{\text {by }} \mathrm{NaHCO}_{3}$.

TABLE 3 | Crop management practices at 14 locations of five countries where the fertilizer experiments were conducted.

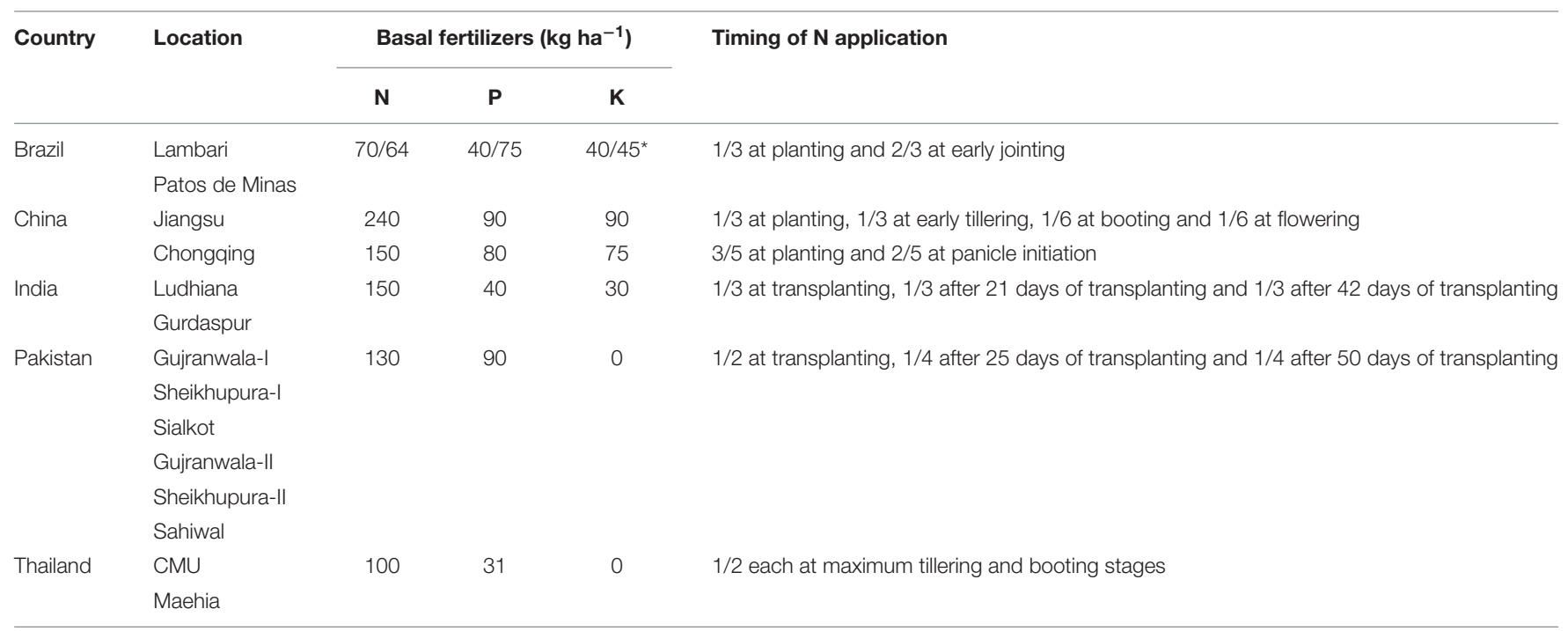

${ }^{*} N, P$, and K basal rates in Brazil are shown for the years 2016/2017, respectively.

compared by the paired t test using SPSS 13.0 for Windows. The linear models were used to evaluate correlations among various parameters using MS Excel.

\section{RESULTS}

\section{Grain Yield}

With the same experimental treatments, rice grain (paddy) yields varied drastically across 21 field sites across 14 locations in five countries. For example, in case of the local control treatment (i.e., no micronutrient application), rice grain yield varied from $1.94 \mathrm{Mg} \mathrm{ha}^{-1}$ at Lambari location of Brazil in 2017 to 11.46 $\mathrm{Mg} \mathrm{ha}^{-1}$ at Jiangsu location of China in 2015 (Table 4). Foliar application of $\mathrm{Zn}$, I or micronutrient cocktail did not affect rice grain yield at any field site in any country. Across all experimental treatments and field sites in five countries, average grain yield was $6.10 \mathrm{Mg} \mathrm{ha}^{-1}$ with the local control treatment, $6.26 \mathrm{Mg}$ $\mathrm{ha}^{-1}$ with the foliar $\mathrm{Zn}$ treatment, $5.95 \mathrm{Mg} \mathrm{ha}^{-1}$ with the foliar I treatment, and $6.06 \mathrm{Mg} \mathrm{ha}^{-1}$ with the micronutrient cocktail treatment (Table 4).

\section{Grain Zn, I, Fe and Se Concentration}

With the local control treatment, brown rice $\mathrm{Zn}$ concentration ranged from $15.0 \mathrm{mg} \mathrm{kg}^{-1}$ at the Ludhiana field site of India in 2017 to $26.9 \mathrm{mg} \mathrm{kg}^{-1}$ at CMU field site of Thailand in 2015 (Table 5). Application of foliar $\mathrm{Zn}$ and micronutrient cocktail significantly increased $\mathrm{Zn}$ concentration in brown rice at all 
TABLE 4 | Grain yield of rice grown with different foliar fertilizer treatments at 21 field sites in 14 locations of five countries.

\begin{tabular}{|c|c|c|c|c|c|c|c|}
\hline \multirow[t]{2}{*}{ Country } & \multirow[t]{2}{*}{ Location } & \multirow[t]{2}{*}{ Year } & \multicolumn{4}{|c|}{ Grain yield (Mg ha $\left.{ }^{-1}\right)$} & \multirow[t]{2}{*}{$F$-test at $p<0.05$} \\
\hline & & & Local control & Foliar Zn & Foliar I & Foliar cocktail & \\
\hline \multirow[t]{4}{*}{ Brazil } & Lambari & 2016 & 2.23 & 2.35 & 2.15 & 2.27 & NS \\
\hline & & 2017 & 1.94 & 1.88 & 2.10 & 2.33 & NS \\
\hline & Patos de Minas & 2016 & 4.55 & 5.30 & 5.02 & 5.52 & NS \\
\hline & & 2017 & 5.98 & 5.53 & 4.86 & 5.09 & NS \\
\hline \multirow[t]{3}{*}{ China } & Jiangsu & 2015 & 11.46 & 11.11 & 11.62 & 11.24 & NS \\
\hline & & 2016 & 9.34 & 9.61 & 9.56 & 9.28 & NS \\
\hline & Chongqing & 2016 & 10.73 & 10.08 & 10.90 & 10.39 & NS \\
\hline \multirow[t]{4}{*}{ India } & Ludhiana & 2016 & 8.08 & 8.36 & 7.84 & 8.31 & NS \\
\hline & & 2017 & 8.33 & 8.26 & 7.68 & 7.61 & NS \\
\hline & Gurdaspur & 2016 & 8.03 & 8.05 & 7.92 & 7.98 & NS \\
\hline & & 2017 & 8.41 & 8.38 & 8.28 & 8.15 & NS \\
\hline \multirow[t]{6}{*}{ Pakistan } & Gujranwala-I & 2016 & 5.42 & $\mathrm{Nd}$ & 5.40 & 5.56 & NS \\
\hline & Sheikhupura-I & 2016 & 4.61 & $\mathrm{Nd}$ & 4.48 & 4.67 & NS \\
\hline & Sialkot & 2016 & 5.51 & $\mathrm{Nd}$ & 5.41 & 5.51 & NS \\
\hline & Gujranwala-II & 2017 & 4.56 & 4.81 & 4.47 & 4.46 & NS \\
\hline & Sheikhupura-II & 2017 & 4.59 & 4.70 & 4.73 & 4.94 & NS \\
\hline & Sahiwal & 2017 & 4.25 & 4.28 & 4.42 & 4.46 & NS \\
\hline \multirow[t]{4}{*}{ Thailand } & $\mathrm{CMU}$ & 2015 & 6.51 & 6.55 & 6.08 & 6.07 & NS \\
\hline & & 2016 & 4.57 & 4.13 & 3.87 & 4.01 & NS \\
\hline & Maehia & 2015 & 5.01 & 4.87 & 4.66 & 5.20 & NS \\
\hline & & 2016 & 4.06 & 4.54 & 3.64 & 4.41 & NS \\
\hline Mean & & & 6.10 & 6.26 & 5.95 & 6.06 & \\
\hline
\end{tabular}

$\mathrm{Nd}$, no data (due to an experimental error in the field, grain yield could not be collected). NS, non-significantly different at $P<0.05$.

field sites in all countries $(P<0.05)$, except for at Ludhiana field site of India in both years and at Gurdaspur field site of India in 2016 (Table 5). Average increase in brown rice $\mathrm{Zn}$ concentration, across all field sites in five countries, was $31.3 \%$ with foliar $\mathrm{Zn}$ application and $25.2 \%$ with foliar micronutrient cocktail application.

The range in I concentration in brown rice was wider than the range in $\mathrm{Zn}$ concentration. In the case of the local control treatment, I concentration varied from $4 \mu \mathrm{g} \mathrm{kg}-1$ at Ludhiana and Gurdaspur field sites of India in 2016 and 2017, respectively to $34 \mu \mathrm{g} \mathrm{kg}^{-1}$ at Patos de Minas field site of Brazil in 2017. Foliar application of I and micronutrient cocktail resulted in several fold increases in brown rice I concentration at all field sites in all countries $(P<0.05$; Table 6). On average, across all field sites in all countries, rice grain I concentration was $11 \mu \mathrm{g} \mathrm{kg}^{-1}$ with the local control, $204 \mu \mathrm{g} \mathrm{kg}^{-1}$ with the foliar I, and $181 \mu \mathrm{g} \mathrm{kg}^{-1}$ with the foliar micronutrient cocktail applications.

Variation in $\mathrm{Fe}$ concentration in brown rice across all field sites with the local control treatment was greater than the variation in grain $\mathrm{Zn}$ concentration. With this treatment, brown rice Fe concentration showed a range between $8.0 \mathrm{mg} \mathrm{kg} \mathrm{kg}^{-1}$ at Gurdaspur field site of India in 2016 and $27.8 \mathrm{mg} \mathrm{kg}^{-1}$ at Jiangsu field site of China in 2015 (Table 7). However, unlike brown rice $\mathrm{Zn}$ density, rice grain Fe concentration was not affected by foliar application of micronutrient cocktail, except for two field sites in Brazil, i.e., Lambari in 2016 and Patos de Minas in 2017. Consequently, average brown rice $\mathrm{Fe}$ concentration with all experimental treatments remained almost the same, i.e., $11.8-12.8 \mathrm{mg} \mathrm{Fe} \mathrm{kg}^{-1}$ grains (Table 7).

The Se concentration in brown rice across all field locations showed a large variation with the same micronutrient treatment. With the local control treatment, it was $3 \mu \mathrm{g} \mathrm{Se} \mathrm{kg}^{-1}$ at Patos de Minas, Brazil in 2016 to as high as $404 \mu \mathrm{g} \mathrm{Se} \mathrm{kg} \mathrm{kg}^{-1}$ at Ludhiana, India in 2017 (Table 8). The foliar application of the micronutrient cocktail resulted in substantial increases in Se concentration in brown rice at all field locations in all countries $(P<0.05)$; the overall magnitude of increase in grain Se concentration was 4-fold (Table 8).

\section{Relationships Between Rice Grain and Soil Concentrations of $\mathrm{Zn}, \mathrm{I}, \mathrm{Fe}$ and Se}

The relationships between soil extractable micronutrient concentrations and their grain concentrations are presented in Figure 1. There was even no correlation between soil extractable concentrations of $\mathrm{I}, \mathrm{Fe}$ and $\mathrm{Se}$ and the concentrations of these micronutrients in rice grain. In fact, there even a negative relation between soil extractable $\mathrm{Zn}$ and grain $\mathrm{Zn}$ concentration in rice $\left(\mathrm{R}^{2}=0.17, P<0.05\right)$.

\section{DISCUSSION}

Results of the present study conducted across 21 field sites over two crop seasons in five major rice-growing countries showed that the foliar application of a micronutrient cocktail solution 
TABLE 5 | Zinc concentration in brown rice grains grown with different foliar fertilizer treatments in 14 locations of five countries.

\begin{tabular}{|c|c|c|c|c|c|c|c|}
\hline \multirow[t]{2}{*}{ Country } & \multirow[t]{2}{*}{ Location } & \multirow[t]{2}{*}{ Year } & \multicolumn{4}{|c|}{ Grain $\mathrm{Zn}$ concentration $\left(\mathrm{mg} \mathrm{kg}^{-1}\right)$} & \multirow[t]{2}{*}{ F-test at $p<0.05$} \\
\hline & & & Local control & Foliar Zn & Foliar I & Foliar cocktail & \\
\hline \multirow[t]{4}{*}{ Brazil } & Lambari & 2016 & $22.4 \mathrm{a}$ & $28.8 b$ & $23.6 \mathrm{a}$ & $28.2 b$ & * \\
\hline & & 2017 & $25.2 \mathrm{a}$ & $32.2 \mathrm{~b}$ & $25.5 \mathrm{a}$ & $30.5 b$ & * \\
\hline & Patos de Minas & 2016 & $23.8 \mathrm{a}$ & $28.5 b$ & $23.9 \mathrm{a}$ & $28.1 \mathrm{~b}$ & * \\
\hline & & 2017 & $21.6 \mathrm{a}$ & $27.4 \mathrm{~b}$ & $21.7 \mathrm{a}$ & $27.7 b$ & * \\
\hline \multirow[t]{3}{*}{ China } & Jiangsu & 2015 & $19.3 \mathrm{a}$ & $27.8 b$ & $20.9 \mathrm{a}$ & $27.1 \mathrm{~b}$ & * \\
\hline & & 2016 & $26.0 \mathrm{a}$ & $40.5 b$ & $28.1 \mathrm{a}$ & 39.8 b & * \\
\hline & Chongqing & 2016 & $17.8 \mathrm{a}$ & $21.4 b$ & $17.8 \mathrm{a}$ & $21.4 b$ & * \\
\hline \multirow[t]{4}{*}{ India } & Ludhiana & 2016 & 21.8 & 25.8 & 21.8 & 21.8 & NS \\
\hline & & 2017 & 15.0 & 22.7 & 17.0 & 21.6 & NS \\
\hline & Gurdaspur & 2016 & 21.2 & 25.0 & 23.0 & 23.6 & NS \\
\hline & & 2017 & $16.8 \mathrm{a}$ & $18.4 \mathrm{~b}$ & $17.3 \mathrm{a}$ & 19.2 b & * \\
\hline \multirow[t]{6}{*}{ Pakistan } & Gujranwala-I & 2016 & $20.9 a$ & $\mathrm{Nd}$ & $21.9 \mathrm{a}$ & $31.5 b$ & * \\
\hline & Sheikhupura-I & 2016 & $19.2 \mathrm{a}$ & $\mathrm{Nd}$ & $18.7 \mathrm{a}$ & $25.3 b$ & * \\
\hline & Sialkot & 2016 & $18.7 \mathrm{a}$ & $\mathrm{Nd}$ & $18.0 \mathrm{a}$ & $23.0 \mathrm{~b}$ & * \\
\hline & Gujranwala-II & 2017 & $18.5 \mathrm{a}$ & $24.3 b$ & $18.3 \mathrm{a}$ & $22.0 \mathrm{~b}$ & * \\
\hline & Sheikhupura-II & 2017 & 18.6 a & $23.2 \mathrm{~b}$ & $18.8 \mathrm{a}$ & $22.9 \mathrm{~b}$ & * \\
\hline & Sahiwal & 2017 & $19.0 \mathrm{a}$ & $27.3 b$ & 19.6 a & $27.3 b$ & * \\
\hline \multirow[t]{4}{*}{ Thailand } & $\mathrm{CMU}$ & 2015 & $26.9 a$ & $31.5 b$ & $26.1 \mathrm{a}$ & $33.0 \mathrm{~b}$ & * \\
\hline & & 2016 & $27.3 \mathrm{a}$ & $30.4 b$ & $25.5 \mathrm{a}$ & $27.8 \mathrm{~b}$ & * \\
\hline & Maehia & 2015 & $26.5 \mathrm{a}$ & $31.6 \mathrm{~b}$ & $27.4 \mathrm{a}$ & $31.7 b$ & * \\
\hline & & 2016 & $23.3 \mathrm{a}$ & $39.6 \mathrm{~b}$ & $23.3 \mathrm{a}$ & 29.6 b & * \\
\hline \multicolumn{3}{|l|}{ Mean } & 21.4 & 28.1 & 21.8 & 26.8 & \\
\hline \multicolumn{3}{|c|}{$\%$ increase in grain Zn concentration over local control treatment } & & $31.3 \%$ & - & $25.2 \%$ & \\
\hline
\end{tabular}

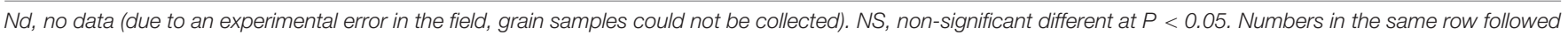
by different letters differ significantly at $L S D_{0.05} \cdot{ }^{*}=$ significantly different at $P<0.05$.

was highly effective in increasing brown rice grain concentrations of $\mathrm{Zn}, \mathrm{I}$ and Se. The increases in grain concentration of micronutrients happened without any clear change in grain yield by application of the cocktail solution of micronutrients (Table 4). The soils of all the field sites were not deficient in $\mathrm{Zn}$ and $\mathrm{Fe}$ for rice, and contained generally high extractable concentrations of $\mathrm{Zn}$ and especially Fe (Sims and Johnson, 1991). The DTPA-extractable soil $\mathrm{Zn}$ and $\mathrm{Fe}$ concentrations ranged between 0.6 to $3.7 \mathrm{mg} \mathrm{kg}^{-1}$ and 14 to $176 \mathrm{mg} \mathrm{kg}^{-1}$, respectively (Table 2). Although several soil chemical and biological factors are known to affect the interpretation of the effect of soil DTPAextractable $\mathrm{Zn}$ on plant growth, it can be, however, generalized that the rice plants may respond to $\mathrm{Zn}$ fertilization positively if the DTPA-extractable $\mathrm{Zn}$ is below $0.5 \mathrm{mg} \mathrm{kg}^{-1}$ (Sims and Johnson, 1991; Fageria, 2013; Duffner et al., 2014). Also, foliar application of $\mathrm{Zn}$ is less effective in increasing grain yield of crops compared with its soil application (Zou et al., 2012). Lack of grain yield increase in response to foliar application of $\mathrm{Zn}$ and Fe across these field sites could be attributed to adequate amount of DTPA-extractable $\mathrm{Zn}$ and Fe for rice (Table 2).

To our knowledge, this study is the first one showing a very positive effect of combined foliar sprays of $\mathrm{Zn}$, I and Se on grain concentrations of these micronutrients in many rice cultivars grown in several countries. A similar positive effect of the foliar applied micronutrient cocktail solution on grain concentrations of the micronutrients has been also shown in wheat grown in 6 different countries (Zou et al., 2019). In contrast to $\mathrm{Zn}$, $\mathrm{I}$ and $\mathrm{Se}$, the concentration of $\mathrm{Fe}$ in grain was not affected with the spray of the micronutrient cocktail (Table 7). There was only a minimal increasing trend in grain $\mathrm{Fe}$ (by about $8 \%$ ) by spray of micronutrient cocktail solution. Also, foliar applications of $\mathrm{Zn}$ to rice foliage in both single and cocktail solutions were also effective in increasing $\mathrm{Zn}$ concentration of brown rice grains at most of the field sites $(P<0.05$; Table 5). The positive effect of foliar application of $\mathrm{Zn}$ alone on grain $\mathrm{Zn}$ has been shown already in rice (Phattarakul et al., 2012; Mabesa et al., 2013; Goloran et al., 2019). In the present study, the positive impact of foliar $\mathrm{Zn}$ application on grain $\mathrm{Zn}$ was consistent during both years at all field sites in five different countries, with the exception of a few field sites in India (Table 5). There was, however, a distinct genotypic variation in response to foliar Zn fertilization. For example, the cultivar Zhengdao11 from the Jiangsu location in China consistently showed the highest response to foliar $\mathrm{Zn}$ fertilization over 2 years and exhibited an increase over 50\%, while the cultivar Xiyou19 from Chongqing in China showed an increase of around $17 \%$ only (Table 5). Both rice cultivars used in India (i.e., PR 124 and $\mathrm{PR}$ 121) were less responsive to foliar $\mathrm{Zn}$ application in terms of increasing grain $\mathrm{Zn}$. It is well-documented that rice cultivars show a large variation in their ability to translocate and deposit $\mathrm{Zn}$ in the grains (Impa et al., 2013; Johnson-Beebout et al., 2016; Sanjeeva Rao et al., 2020). 

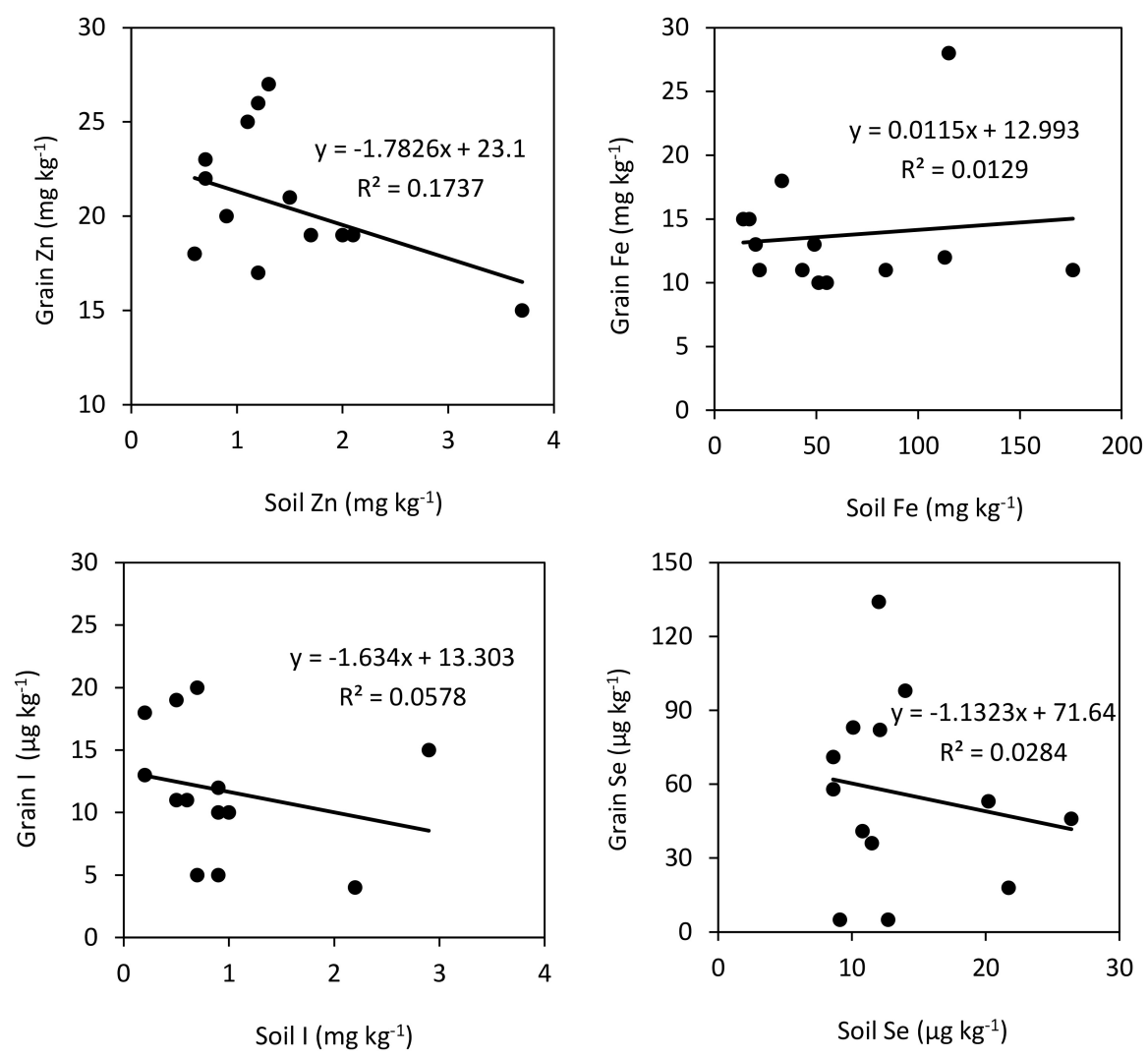

FIGURE 1 | Correlations between soil and grain concentrations of Zn, I, Fe, and Se in plants grown without foliar treatments. Soil Zn and Fe represent their DTPA-extractable concentrations, while soil Se and I are $0.1 \mathrm{M} \mathrm{KH}_{2} \mathrm{PO}_{4}$ extractable and TMAH-extractable concentrations, respectively.

The weak of relationship between grain $\mathrm{Zn}$ and DTPAextractable soil $\mathrm{Zn}$ (Figure 1) indicates that retranslocation of $\mathrm{Zn}$ from the vegetative parts to grains, rather than the root $\mathrm{Zn}$ uptake, might be a key process affecting grain $\mathrm{Zn}$ accumulation in different rice genotypes grown in five countries. In agreement with this suggestion, Mabesa et al. (2013) and Impa et al. (2013) showed that grain $\mathrm{Zn}$ accumulation in rice genotypes is under a significant influence of $\mathrm{Zn}$ remobilization and transport from vegetative parts to grains. However, the relationship between the concentrations of two mineral nutrients existing in the soil and grain depends not only on their chemical availability, but also on the available amount of other mineral nutrients in soil. It is well documented that there is antagonistic interaction among the mineral nutrients during their root uptake and root-to-shoot transport which greatly affects the leaf and grain composition of mineral nutrients (Marschner, 2012; Rietra et al., 2017). Therefore, the weak correlation between the micronutrients in soil and grain (Figure 1) may also depend on the antagonism between nutrients during root uptake. In case of some rice genotypes grown under greenhouse conditions, grain $\mathrm{Zn}$ has been found to be in good correlation with the DTPA-extractable soil Zn (Fageria et al., 2011; Johnson-Beebout et al., 2016). Based on these results, it has been suggested that keeping adequate plant available $\mathrm{Zn}$ in the soil medium until grain maturation would contribute greatly to grain $\mathrm{Zn}$ accumulation through continued and direct root uptake of $\mathrm{Zn}$ with little reliance on retranslocation of $\mathrm{Zn}$ from vegetative tissues (Johnson-Beebout et al., 2016; Cakmak and Kutman, 2018). Generally, grain Zn correlates very positively with the amount of $\mathrm{Zn}$ in the growth medium if $\mathrm{Zn}$ is continuously supplied or remains available to the plant roots until grain maturation, which is very common under controlled greenhouse or growth chamber studies. By contrast, when soil $\mathrm{Zn}$ availability to plant roots is limited especially during reproductive growth stage, which is very common under field conditions, grain $\mathrm{Zn}$ accumulation largely depends on remobilization of $\mathrm{Zn}$ from vegetative tissues (Stomph et al., 2009; Waters et al., 2009; Cakmak and Kutman, 2018). Therefore, it can be suggested that the rice genotypes with higher mobilization and translocation capacity for $\mathrm{Zn}$ (and also other micronutrients) from the vegetative tissues to grain are potentially the most promising genotypes for higher grain $\mathrm{Zn}$ accumulation.

It was important to note that across all field sites, the average $\mathrm{Zn}$ concentration in rice grains with foliar application of $\mathrm{Zn}$ alone (i.e., $28.1 \mathrm{mg} \mathrm{kg}^{-1}$; Table 5) was very similar to the increase achieved by the cocktail spray of micronutrients (i.e., 26. $8 \mathrm{mg} \mathrm{kg}^{-1}$ ). This result clearly indicates that when applied together with three other micronutrients, the leaf absorption and transportation of $\mathrm{Zn}$ in the grain are not seriously affected by the other micronutrients present in the same spray solution. Foliar application of $\mathrm{KIO}_{3}$ alone had no effect on rice grain $\mathrm{Zn}$ and even 
TABLE 6 | lodine concentration in brown rice grains grown with different foliar fertilizer treatments at 21 field sites in 14 locations of five countries.

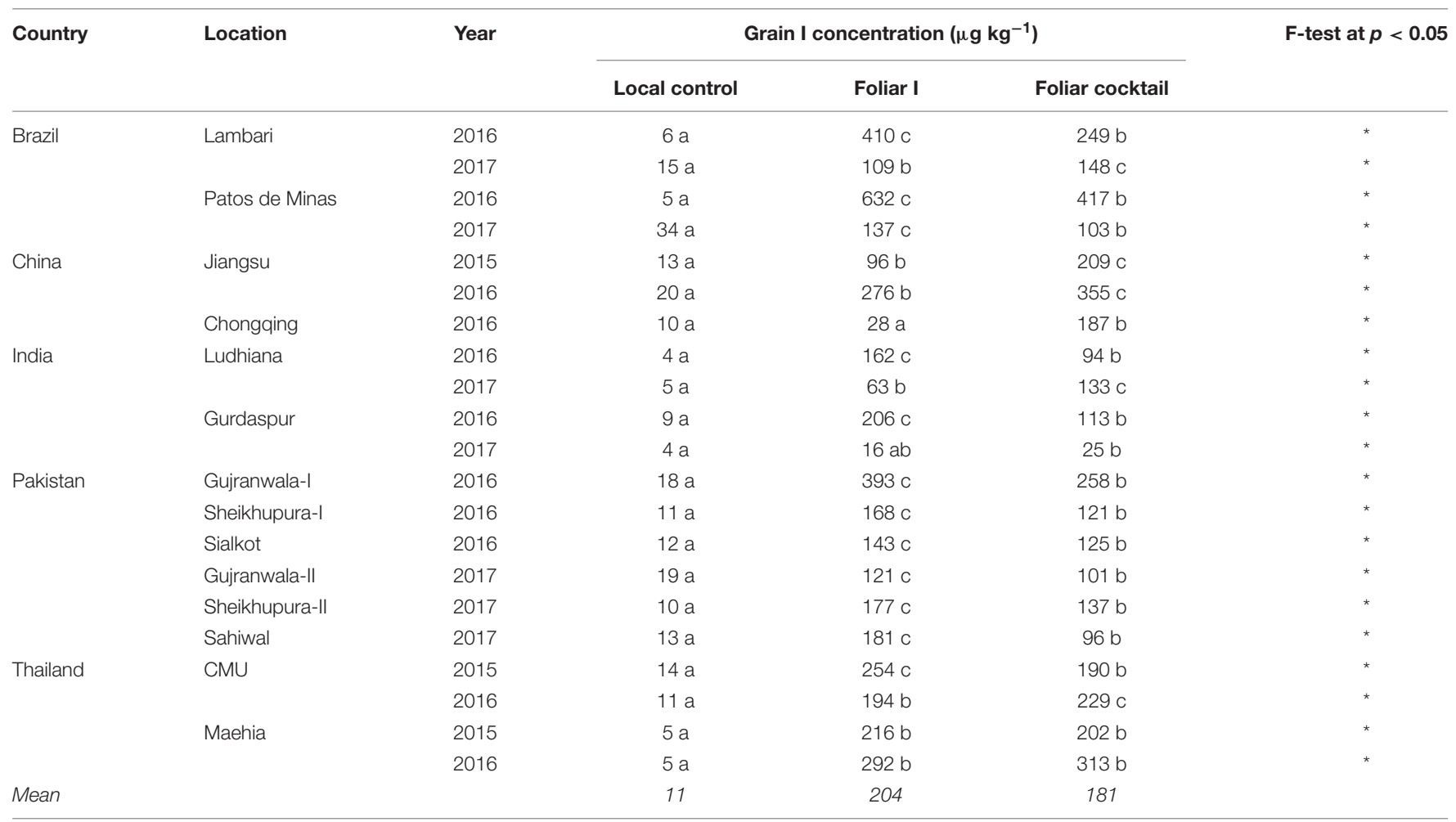

Numbers in the same row followed by different letters differ significantly at $L S D_{0.05}{ }^{*}=$ significantly different at $P<0.05$.

TABLE 7 | Iron concentration in brown rice grains grown with different foliar fertilizer treatments at 21 field sites in 14 locations of five countries.

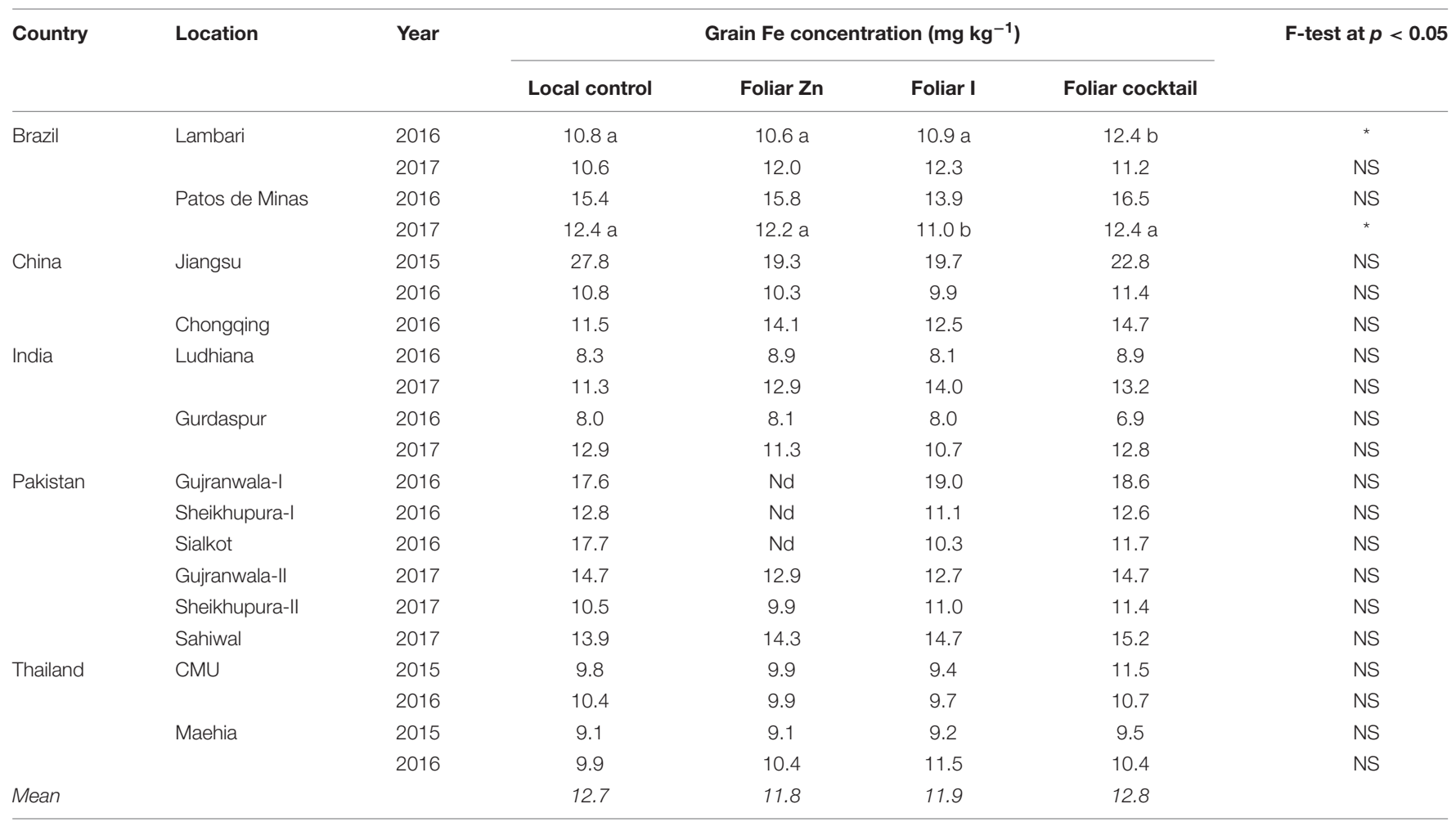

Nd, no data; NS, non-significant different at $P<0.05$. Numbers in the same row followed by different letters differ significantly at $L S D_{0.05} \cdot{ }^{*}=$ significantly different at $P<0.05$. 
TABLE 8 | Selenium concentration in brown rice grains grown with different foliar fertilizer treatments at 21 field sites in 14 locations of five countries.

\begin{tabular}{|c|c|c|c|c|c|}
\hline \multirow[t]{2}{*}{ Country } & \multirow[t]{2}{*}{ Location } & \multirow[t]{2}{*}{ Year } & \multicolumn{2}{|c|}{$\begin{array}{c}\text { Grain Se } \\
\text { concentration ( } \mu \mathrm{g} \\
\left.\mathbf{k g}^{-1}\right)\end{array}$} & \multirow[t]{2}{*}{$\begin{array}{l}F \text {-test at } \\
p<0.05\end{array}$} \\
\hline & & & $\begin{array}{l}\text { Local } \\
\text { control }\end{array}$ & $\begin{array}{l}\text { Foliar } \\
\text { cocktail }\end{array}$ & \\
\hline \multirow[t]{4}{*}{ Brazil } & Lambari & 2016 & $9 a$ & $262 b$ & * \\
\hline & & 2017 & $5 a$ & $172 \mathrm{~b}$ & $\star$ \\
\hline & Patos de Minas & 2016 & $3 a$ & $313 b$ & * \\
\hline & & 2017 & $5 \mathrm{a}$ & $352 \mathrm{~b}$ & * \\
\hline \multirow[t]{3}{*}{ China } & Jiangsu & 2015 & $32 \mathrm{a}$ & $231 b$ & * \\
\hline & & 2016 & $41 \mathrm{a}$ & $562 \mathrm{~b}$ & * \\
\hline & Chongqing & 2016 & $18 \mathrm{a}$ & $90 \mathrm{~b}$ & $\star$ \\
\hline \multirow[t]{4}{*}{ India } & Ludhiana & 2016 & $290 \mathrm{a}$ & $543 \mathrm{~b}$ & * \\
\hline & & 2017 & $404 \mathrm{a}$ & $602 \mathrm{~b}$ & * \\
\hline & Gurdaspur & 2016 & $111 \mathrm{a}$ & $279 b$ & * \\
\hline & & 2017 & $83 \mathrm{a}$ & $191 b$ & * \\
\hline \multirow[t]{6}{*}{ Pakistan } & Gujranwala-I & 2016 & $46 \mathrm{a}$ & $519 b$ & * \\
\hline & Sheikhupura-I & 2016 & $82 \mathrm{a}$ & $420 \mathrm{~b}$ & * \\
\hline & Sialkot & 2016 & 98 a & $376 b$ & * \\
\hline & Gujranwala-II & 2017 & $58 \mathrm{a}$ & 296 b & * \\
\hline & Sheikhupura-II & 2017 & $53 a$ & $275 b$ & * \\
\hline & Sahiwal & 2017 & $71 \mathrm{a}$ & $506 \mathrm{~b}$ & * \\
\hline \multirow[t]{4}{*}{ Thailand } & $\mathrm{CMU}$ & 2015 & $23 \mathrm{a}$ & $449 b$ & * \\
\hline & & 2016 & $134 \mathrm{a}$ & $423 b$ & * \\
\hline & Maehia & 2015 & $41 \mathrm{a}$ & $530 \mathrm{~b}$ & * \\
\hline & & 2016 & $36 \mathrm{a}$ & $584 \mathrm{~b}$ & * \\
\hline Mean & & & 95 a & $380 b$ & \\
\hline \multicolumn{3}{|c|}{$\begin{array}{l}\text { fold increase in brown rice grain Se over } \\
\text { local control treatment }\end{array}$} & & 4 & \\
\hline
\end{tabular}

Numbers in the same row followed by different letters differ significantly at $L S D_{0.05}$. ${ }^{*}=$ Significantly different at $P<0.05$.

tended to increase grain $\mathrm{Zn}$ (Table 5). A very similar finding has been also reported in field studies conducted on wheat grown in six countries (Zou et al., 2019). The lack of antagonism between $\mathrm{Zn}$ and Se (Mangueze et al., 2018) or Fe and Zn (Wei et al., 2012) has been also shown in rice when these micronutrients are sprayed together in the same spray solution.

Iodine is not an essential micronutrient for higher plants (Marschner, 2012) but, food crops absorb, transport and accumulate I in edible parts (Fuge and Johnson, 2015; Cakmak et al., 2017; Gonzali et al., 2017). There are a few studies indicating that I has some beneficial effects on plant growth, however, I might be also phytotoxic when applied at higher concentrations (Medrano-Macías et al., 2016; Gonzali et al., 2017). In the present study, substantial increases were found in grain I with the foliar application of $\mathrm{KIO}_{3}$ (Table 6). This significant effect of $\mathrm{KIO}_{3}$ on grain I was consistent over two years across the 21 field sites $(P<0.05)$ and was observed with the application of I alone or in combination with other micronutrients in the cocktail. There were no clear antagonistic effects of other micronutrients on grain I accumulation when sprayed together (Table 6). Our earlier studies showed that foliar application of $\mathrm{KIO}_{3}$ to rice grown under field conditions in Brazil and Thailand was effective in increasing grain I concentration, and similar positive effects were also found with the foliar application of KI (Cakmak et al., 2017). These results suggested that $I$ is transported to grains via the phloem channel. There are, however, different opinions and discussions regarding phloem mobility of I. Very recently, Golob et al. (2020) showed that foliar-applied I either in the form of KI or $\mathrm{KIO}_{3}$ significantly enhanced I concentration in the tubers of kohlrabi plants, indicating phloem transport of $\mathrm{I}$ in the plants. Similar findings related to phloem transportation of I have been also reported by Smoleń et al. (2016) and Landini et al. (2011). By contrast, there are studies showing poor phloem transport of $\mathrm{I}$ in the plants such as in young spinach plants (Humphrey et al., 2019) and apple trees (Budke et al., 2020). In case of the studies with apple trees, the increases in I concentration of the fruits, which were kept in plastic bags during the foliar spray, were around 4 - to 5-fold compared to the trees without foliar I spray (i.e., from $0.4 \mu \mathrm{g}$ up to $2.0 \mu \mathrm{g}$ per $100 \mathrm{~g} \mathrm{FW}$ ) (Budke et al., 2020). These increases were, indeed, very significant; but the dietary relevance seems to be minimal. As indicated earlier, for cereals, at least a part of the enhanced grain I through foliar spray could be also related to a direct fortification (i.e., contamination) of florets and seeds with I via spray solution (Cakmak et al., 2017). The differences among the plant species in their capacity for transporting I from vegetative tissues to the sink organs (i.e., grains, fruits, tubers) are probably related to the plant species-related factors, concentration of I in spray solution and coverage uniformity of the I spray solution on the leaves. The age of the leaves (i.e., sink or source status of the leaves) of the experimental plants used in the short-term studies might be also another factor. Considering published data and reported large gradient in I concentrations between the sink and source organs (Tsukada et al., 2008; Cakmak et al., 2017; Budke et al., 2020), it can be suggested that I is not highly phloem mobile in the plants, like nitrogen, phosphorus or potassium (Marschner, 2012); but it can be considered as moderately phloem mobile as also suggested by Hurtevent et al. (2013). Further studies are required for better clarification and understanding of the phloem mobility of I in different plant species considering source and sink status of the treated leaves and other factors highlighted above.

The results in Table 6 suggest that grain I concentrations were similar between the foliar sprays of I alone and the cocktail of the micronutrients. As mentioned earlier, there is no antagonistic interactions between $\mathrm{Zn}$ and I during their transport and grain accumulation when sprayed together in the same solution. Similarly, also I and Se seem to be not antagonistic (Table 6). Also in previous studies, no clear interaction was found between I and Se during their leaf absorption and transportation to wheat grains (Zou et al., 2019), lettuce roots (Smoleń et al., 2014), kohlrabi tubers (Golob et al., 2020) and apple fruits (Budke et al., 2020).

The foliar application of the micronutrient cocktail solution was also effective in increasing grain Se concentration at all field sites in five countries $(P<0.05)$. On average, the increase in grain Se with foliar cocktail treatment was 4 -fold (i.e., from $95 \mu \mathrm{g}$ $\mathrm{kg}^{-1}$ to $380 \mu \mathrm{g} \mathrm{kg}^{-1}$; Table 8). Selenium is known to be highly phloem mobile in plants, and therefore foliar spray of Se at relatively low rate is suggested to achieve adequate levels of Se in food crops for human nutrition (Lyons, 2018). Considering the Se concentration in micronutrient cocktail of the present 
study (i.e., $0.001 \% \mathrm{Na}_{2} \mathrm{SeO}_{4}$ ) and two foliar sprays (@ $600 \mathrm{~L}$ cocktail solution $\mathrm{ha}^{-1}$ ) the amount sprayed was about $5 \mathrm{~g} \mathrm{Se}$ $\mathrm{ha}^{-1}$ which resulted in marked increases in grain Se. As rice is a predominant staple cereal in many countries of the world, especially in developing countries, Se-enriched rice through the agronomic biofortification could be a sustainable Se source for the human populations living in Se-deficient regions.

In contrast to $\mathrm{Zn}$, I and Se, foliar spray of the micronutrient cocktail solution did not affect grain Fe concentration compared with the local control treatment, except for one field site in Brazil, i.e., at Lambari in $2016(P<0.05$; Table 7). Usually, there is little change in grain $\mathrm{Fe}$ concentration in response to foliar Fe application which was ascribed to poor mobility of Fe in phloem (Aciksoz et al., 2011; El-Jendoubi et al., 2014). In a field experiment conducted on several Fe-rich rice cultivars in China, Yuan et al. (2013) observed an average increase of about $15 \%$ in Fe concentration of brown rice with foliar-applied $\mathrm{Fe}$ amino acid complex (Fe-AA) alone, and 33\% increase when 1\% $(\mathrm{w} / \mathrm{v})$ nicotianamine was added in the Fe-AA solution $(P<0.05)$. By applying the same micronutrient cocktail solution used in the present study, Zou et al. (2019) found that grain Fe concentration increased only by $13 \%$ in wheat grains grown in 27 locations of 6 countries over 2 years. The effect of foliar Fe sprays on grain Fe reported in the literature is very variable and, usually, of little biological significance (Rengel et al., 1999; Aciksoz et al., 2011; Niyigaba et al., 2019). Due to very low phloem mobility of Fe, transgenic approaches might be useful for enrichment of rice grains with Fe to adequate levels for human nutrition (Wu et al., 2019; Huang et al., 2020).

White rice (polished rice) represents the common form for human consumption; however, its nutritional value is lower than brown rice due to loss of significant amount of minerals during polishing, especially micronutrients such as Fe (Promu-thai et al., 2007; Hansen et al., 2012; Balbinoti et al., 2018). Therefore, a decline in the micronutrient concentrations of rice grain is expected after the polishing process, but the extent of the loss depends on rice cultivars, distribution pattern of the mineral nutrients within grain as well as the degree of milling in polishing process (Prom-u-thai et al., 2007; Hansen et al., 2012; Saenchai et al., 2012).

\section{CONCLUSION}

Foliar application of the cocktail micronutrient solution resulted in significant enrichments of $\mathrm{Zn}$, I and Se in brown rice grains

\section{REFERENCES}

Aciksoz, S. B., Yazici, A., Ozturk, L., and Cakmak, I. (2011). Biofortification of wheat with iron through soil and foliar application of nitrogen and iron fertilizers. Plant Soil 349, 215-225. doi: 10.1007/s11104-0110863-2

Andersson, M., Saltzman, A., Virk, P., and Pfeiffer, W. (2017). Progress update: crop development of biofortified staple food crops under HarvestPlus. Afr. J. Food, Agric. Nutr. Dev. 17, 11905-11935. doi: 10.18697/ajfand.78. HarvestPlus05 under a wide range of environmental and soil conditions of five major rice producing countries. Based on the data published by Statista $\mathrm{GmbH}$ the studied five countries produce almost 300 million metric tons of milled rice which corresponds to about $60 \%$ of world production of milled rice per year (Shahbandeh, 2020). Thus, a successful adoption of this agronomic strategy at least in the five major rice producing countries would contribute significantly to the daily micronutrient intake and alleviation of micronutrient malnutrition. Very recent studies using a simulated human digestive system showed that $\mathrm{Zn}$, I and Se in agronomically biofortified foods are sufficiently bioaccessible for use by the human body (Cakmak et al., 2020). In a further human Zn absorption study conducted at ETH-Zurich, agronomically biofortified wheat with $\mathrm{Zn}$ made a significant contribution to the dietary Zn absorption in humans (Signorell et al., 2019). These new results indicate an effective transfer of micronutrients from field to gut, and highlight relevance of the fertilizer use strategy in fighting the global burden of micronutrient malnutrition in human populations.

\section{DATA AVAILABILITY STATEMENT}

The raw data supporting the conclusions of this article will be made available by the authors, without undue reservation.

\section{AUTHOR CONTRIBUTIONS}

All authors listed have made a substantial, direct and intellectual contribution to the work, and approved it for publication.

\section{FUNDING}

This study was financially supported by the HarvestPlus Program (www.harvestplus.org) and the sponsors of the HarvestPlus Zinc Fertilizer Project Phase-III (www.harvestzinc.org) including $\mathrm{K}+\mathrm{S}$ Kali GmbH, SQM, Mosaic Company, ADOB, International Fertilizer Association, Bayer Crop Science, Valagro, ICL, ATP Nutrition Aglukon, International Zinc Association, and International Plant Nutrition Institute and Research Center for Development of Local Lanna Rice and Rice Products, Chiang Mai University, Thailand.

Bailey, R. L., West, K. P. Jr., and Black, R. E. (2015). The epidemiology of global micronutrient deficiencies. Ann. Nutr. Metab. 66(Suppl. 2), 22-33. doi: 10.1159/ 000371618

Balbinoti, T. C. V., Nicolin, D. J., de Matos Jorge, L. M., and Jorge, R. M. M. (2018). Parboiled rice and parboiling process. Food Eng. Rev. 10, 165-185. doi: 10.1007/s12393-018-9177-y

Black, R. E., Victora, C. G., Walker, S. P., Bhutta, Z. A., Christian, P., de Onis, M., et al. (2013). Maternal and child undernutrition and overweight in lowincome and middle-income countries. Lancet 382, 427-451. doi: 10.1016/ S0140-6736(13)60937-X 
Bouis, H. E., and Saltzman, A. (2017). Improving nutrition through biofortification: a review of evidence from HarvestPlus, 2003 through 2016. Glob. Food Sec. 12, 49-58. doi: 10.1016/j.gfs.2017.01.009

Budke, C., Mühling, K. H., and Daum, D. (2020). Iodine uptake and translocation in apple trees grown under protected cultivation. J. Plant Nutr. Soil Sci. 183, 468-481. doi: 10.1002/jpln.202000099

Cakmak, I. (2008). Enrichment of cereal grains with zinc: agronomic or genetic biofortification? Plant Soil 302, 1-17. doi: 10.1007/s11104-007-9466-3

Cakmak, I., Kalayci, M., Kaya, Y., Torun, A. A., Aydin, N., Wang, Y., et al. (2010). Biofortification and localization of zinc in wheat grain. J. Agric. Food Chem. 58, 9092-9102. doi: 10.1021/jf101197h

Cakmak, I., and Kutman, U. B. (2018). Agronomic biofortification of cereals with zinc: a review. Eur. J. Soil Sci. 69, 172-180. doi: 10.1111/ejss.12437

Cakmak, I., Marzorati, M., Van den Abbeele, P., Hora, K., Holwerda, H. T., Yazici, M. A., et al. (2020). Fate and bioaccessibility of iodine in food prepared from agronomically biofortified wheat and rice and impact of cofertilization with zinc and selenium. J. Agric. Food Chem. 68, 1525-1535. doi: 10.1021/acs.jafc. $9 \mathrm{~b} 05912$

Cakmak, I., Prom-u-thai, C., Guilherme, L. R. G., Rashid, A., Hora, K. H., Yazici, A., et al. (2017). Iodine biofortification of wheat, rice and maize through fertilizer strategy. Plant Soil 418, 319-335. doi: 10.1007/s11104-017-3295-9

Camaschella, C. (2019). Iron deficiency. Blood 133, 30-39. doi: 10.1182/blood2018-05-815944

de Valença, A. W., Bake, A., Brouwer, I. D., and Giller, K. E. (2017). Agronomic biofortification of crops to fight hidden hunger in sub-Saharan Africa. Glob. Food Sec. 12, 8-14. doi: 10.1016/j.gfs.2016.12.001

Dhillon, K. S., Rani, N., and Dhillon, S. K. (2005). Evaluation of different extractants for the estimation of bioavailable selenium in seleniferous soils of Northwest India. Soil Res. 43, 639-645. doi: 10.1071/SR04166

Dimkpa, C. O., and Bindraban, P. S. (2016). Fortification of micronutrients for efficient agronomic production: a review. Agron Sustain Dev. 36:7. doi: 10.1007/ s13593-015-0346-6

Duffner, A., Hoffland, E., Stomph, T. J., Melse-Boonstra, A., and Bindraban, P. S. (2014). Elimination zinc deficiency in rice-based systems. Virtual Fertilizer Research Center / VFRC Report 2014/12. Washington, DC: Virtual Fertilizer Research Center.

El-Jendoubi, H., Vázquez, S., Calatayud, A., Vavpetiè, P., Vogel-Mikuš, K., Pelicon, P., et al. (2014). The effects of foliar fertilization with iron sulfate in chlorotic leaves are limited to the treated area. A study with peach trees (Prunus persica L. Batsch) grown in the field and sugar beet (Beta vulgaris L.) grown in hydroponics. Front. Plant Sci. 5:2. doi: 10.3389/fpls.2014.00002

Fageria, N. (2013). Mineral Nutrition of Rice, 1st Edn. Boca Raton, FL: CRC Press.

Fageria, N. K., dos Santos, A. B., and Cobucci, T. (2011). Zinc nutrition of lowland rice. Commun. Soil Sci. Plant Anal. 42, 1719-1727. doi: 10.1080/00103624.2011. 584591

Fuge, R., and Johnson, C. (2015). Iodine and human health, the role of environmental geochemistry and diet, a review. Appl. Geochem. 63, 282-302. doi: 10.1016/j.apgeochem.2015.09.013

Gödecke, T., Stein, A. J., and Qaim, M. (2018). The global burden of chronic and hidden hunger: trends and determinants. Glob. Food Sec. 17, 21-29. doi: 10.1016/j.gfs.2018.03.004

Golob, A., Novak, T., Maršiæ, N. K., Šircelj, H., Stibilj, V., Jerše, A., et al. (2020). Biofortification with selenium and iodine changes morphological properties of Brassica oleracea L. var. gongylodes) and increases their contents in tubers. Plant Physiol. Biochem. 150, 234-243. doi: 10.1016/j.plaphy.2020. 02.044

Goloran, J. B., Johnson-Beebout, S. E., Morete, M. J., Impa, S. M., Kirk, G. J. D., and Wissuwa, M. (2019). Grain Zn concentrations and yield of Zn-biofortified versus $\mathrm{Zn}$-efficient rice genotypes under contrasting growth conditions. Field Crops Res. 234, 26-32. doi: 10.1016/j.fcr.2019.01.011

Gonzali, S., Kiferle, C., and Perata, P. (2017). Iodine biofortification of crops: agronomic biofortification, metabolic engineering and iodine bioavailability. Curr. Opin. Biotechnol. 44, 16-26. doi: 10.1016/j.copbio.2016.10.004

Hansen, T. H., Lombi, E., Fitzgerald, M., Laursen, K. H., Frydenvang, J., Husted, S., et al. (2012). Losses of essential mineral nutrients by polishing of rice differ among genotypes due to contrasting grain hardness and mineral distribution. J. Cereal Sci. 56, 307-315. doi: 10.1016/j.jcs.2012.07.002
Harding, K. L., Aguayo, V. M., and Webb, P. (2018). Hidden hunger in South Asia: a review of recent trends and persistent challenges. Public Health Nutr. 21, 785-795. doi: 10.1017/S1368980017003202

HarvestPlus (2020). Getting Biofortified Food on Everyone's Plate: 2019 HarvestPlus Annual Report. Avaliable at: https://www.harvestplus.org/knowledge-market/ in-the-news/getting-biofortified-food-everyone $\% \mathrm{E} 2 \% 80 \% 99$ s-plate- 2019 harvestplus-annual (accessed June 20, 2020).

Huang, S., Wang, P., Yamaji, N., and Ma, J. F. (2020). Plant nutrition for human nutrition: hints from rice research and future perspectives. Mol. Plant 13, 825-835. doi: 10.1016/j.molp.2020.05.007

Humphrey, O., Young, S., Bailey, E., Crout, N., Ander, E., Hamilton, E., et al. (2019). Iodine uptake, storage and translocation mechanisms in spinach (Spinacia oleracea L.). Environ. Geochem. Health 41, 2145-2156. doi: 10.1007/ s10653-019-00272-z

Hurtevent, P., Thiry, Y., Levchuk, S., Yoschenko, V., Henner, P., Madoz-Escande, C., et al. (2013). Translocation of $125 \mathrm{I}, 75 \mathrm{Se}$ and $36 \mathrm{Cl}$ to wheat edible parts following wet foliar contamination under field conditions. J. Environ. Radioact. 121, 43-54. doi: 10.1016/j.jenvrad.2012.04.013

Impa, S. M., Gramlich, A., Tandy, S., Schulin, R., Frossard, E., and JohnsonBeebout, S. E. (2013). Internal $\mathrm{Zn}$ allocation influences $\mathrm{Zn}$ deficiency tolerance and grain Zn loading in rice (Oryza sativa L.). Front. Plant Sci. 4:534. doi: 10.3389/fpls.2013.00534

Ito, V. C., and Lacerda, L. G. (2019). Black rice (Oryza sativa L.): a review of its historical aspects, chemical composition, nutritional and functional properties, and applications and processing technologies. Food Chem. 301:125304. doi: 10.1016/j.foodchem.2019.125304

Jha, A. B., and Warkentin, T. D. (2020). Biofortification of pulse crops: status and future perspectives. Plants 9:73. doi: 10.3390/plants9010073

Johnson-Beebout, S. E., Goloran, J. B., Rubianes, F. H. C., Jacob, J. D. C., and Castillo, O. B. (2016). Zn uptake behavior of rice genotypes and its implication on grain Zn biofortification. Sci. Rep. 6:38301. doi: 10.1038/srep38301

Jones, G. D., Droz, B., Greve, P., Gottschalk, P., Poffet, D., McGrath, S. P., et al. (2017). Selenium deficiency risk predicted to increase under future climate change. Proc. Natl. Acad. Sci. U.S.A. 114, 2848-2853. doi: 10.1073/pnas. 1611576114

Kutman, U. B., Kutman, B. Y., Ceylan, Y., Ova, E. A., and Cakmak, I. (2012). Contributions of root uptake and remobilization to grain zinc accumulation in wheat depending on post-anthesis zinc availability and nitrogen nutrition. Plant Soil 361, 177-187. doi: 10.1007/s11104-012-1300-x

Landini, M., Gonzali, S., and Perata, P. (2011). Iodine biofortification in tomato. J. Plant. Nutr. Soil Sci. 174, 480-486. doi: 10.1002/jpln.201000395

Lazarus, J. H. (2015). The importance of iodine in public health. Environ. Geochem. Health 37, 605-618. doi: 10.1007/s10653-015-9681-4

Lindsay, W. L., and Norvell, W. A. (1978). Development of a DTPA soil test for zinc, iron, manganese, and copper. Soil Sci. Soc. Am. J. 42, 421-428. doi: $10.2136 /$ sssaj 1978.03615995004200030009x

Lyons, G. (2018). Biofortification of cereals with foliar selenium and iodine could reduce hypothyroidism. Front. Plant Sci. 9:730. doi: 10.3389/fpls.2018. 00730

Mabesa, R. L., Impa, S. M., Grewal, D., and Johnson-Beebout, S. E. (2013). Contrasting grain-Zn response of biofortification rice (Oryza sativa $\mathrm{L}$.) breeding lines to foliar Zn application. Field Crops Res. 149, 223-233. doi: 10.1016/j.fcr. 2013.05.012

Mangueze, A. V. J., Pessoa, M. F. G., Silva, M. J., Ndayiragije, A., Magaia, H. E., Cossa, V. S. I., et al. (2018). Simultaneous Zinc and selenium biofortification in rice. Accumulation, localization and implications on the overall mineral content of the flour. J. Cereal Sci. 82, 34-41. doi: 10.1016/j.jcs.2018.05.005

Mao, H., Wang, J., Wang, Z., Zan, Y., Lyons, G., and Zou, C. (2014). Using agronomic biofortification to boost zinc, selenium, and iodine concentrations of food crops grown on the loess plateau in China. J. Soil Sci. Plant Nutr. 14, 459-470. doi: 10.4067/S0718-95162014005000036

Marschner, P. (2012). Marschner's Mineral Nutrition of Higher Plants, 3rd Edn. Amsterdam: Elsevier.

Medrano-Macías, J., Leija-Martínez, P., González-Morales, S., Juárez-Maldonado, A., and Benavides-Mendoza, A. (2016). Use of iodine to biofortify and promote growth and stress tolerance in crops. Front. Plant Sci. 7:1146. doi: 10.3389/fpls. 2016.01146 
Niyigaba, E., Twizerimana, A., Mugenzi, I., Ngnadong, W. A., Ye, Y. P., Wu, B. M., et al. (2019). Winter wheat grain quality, zinc and iron concentration affected by a combined foliar spray of zinc and iron fertilizers. Agronomy 9:250. doi: 10.3390/agronomy 9050250

Panth, P., Guerin, G., and DiMarco, N. M. (2019). A review of iodine status of women of reproductive age in the USA. Biol. Trace Elem. Res. 188, 208-220. doi: 10.1007/s12011-018-1606-5

Pearce, E. N., Andersson, M., and Zimmermann, M. B. (2013). Global iodine nutrition: where do we stand in 2013? Thyroid 23, 523-528. doi: 10.1089/thy. 2013.0128

Pearce, E. N., Lazarus, J. H., Moreno-Reyes, R., and Zimmermann, M. B. (2016). Consequences of iodine deficiency and excess in pregnant women: an overview of current knowns and unknowns. Am. J. Clin. Nutr. 104(Suppl. 3), 918s-923s. doi: $10.3945 / a j c n .115 .110429$

Phattarakul, N., Rerkasem, B., Li, L., Wu, L., Zou, C., Ram, H., et al. (2012). Biofortification of rice grain with zinc through zinc fertilization in different countries. Plant Soil 361, 131-141. doi: 10.1007/s11104-012$1211-\mathrm{x}$

Prom-u-thai, C., Fukai, S., Godwin, I., and Huang, H. (2007). Genotypic variation of iron partitioning in rice grain. J. Sci. Food Agric. 87, 2049-2054. doi: 10.1002/ jsfa.2961

Ram, H., Rashid, A., Zhang, W., Duarte, A., Phattarakul, N., Simunji, S., et al. (2016). Biofortification of wheat, rice and common bean by applying foliar zinc fertilizer along with pesticides in seven countries. Plant Soil 403, 389-401. doi: $10.1007 / \mathrm{s} 11104-016-2815-3$

Read, S. A., Obeid, S., Ahlenstiel, C., and Ahlenstiel, G. (2019). The role of zinc in antiviral immunity. Adv. Nutr. 10, 696-710. doi: 10.1093/advances/ nmz013

Rengel, Z., Batten, G. D., and Crowley, D. E. (1999). Agronomic approaches for improving the micronutrient density in edible portions of field crops. Field Crops Res. 60, 27-40. doi: 10.1016/S0378-4290(98)00131-2

Rietra, R. P. J. J., Heinen, M., Dimkpa, C. O., and Bindraban, P. S. (2017). Effects of nutrient antagonism and synergism on yield and fertilizer use efficiency. Commun. Soil Sci. Plant Anal. 48, 1895-1920. doi: 10.1080/00103624.2017. 1407429

Saenchai, C., Prom-u-thai, C., Jamjod, S., Dell, B., and Rerkasem, B. (2012). Genotypic variation in milling depression of iron and zinc concentration in rice grain. Plant Soil 361, 271-278. doi: 10.1007/s11104-012-1228-1

Saha, S., Chakraborty, M., Padhan, D., Saha, B., Murmu, S., Batabyal, K., et al. (2017). Agronomic biofortification of zinc in rice: influence of cultivars and zinc application methods on grain yield and zinc bioavailability. Field Crops Res. 210, 52-60. doi: 10.1016/j.fcr.2017.05.023

Sanjeeva Rao, D., Neeraja, C. N., Madhu Babu, P., Nirmala, B., Suman, K., Rao, L. V. S., et al. (2020). Zinc biofortified rice varieties: challenges, possibilities, and progress in India. Front. Nutr. 7:26. doi: 10.3389/fnut.2020. 00026

Shahbandeh, M. (2020). Top countries based on production of milled rice 2018/2019. Avaliable at: https://www.statista.com/statistics/255945/top-countries- ofdestination-for-us-rice-exports-2011/ (accessed July 15, 2020).

Signorell, C., Zimmermann, M. B., Cakmak, I., Wegmüller, R., Zeder, C., Hurrell, R., et al. (2019). Zinc absorption from agronomically biofortified wheat is similar to post-harvest fortified wheat and is a substantial source of bioavailable zinc in humansc:J. Nutr. 149, 840-846. doi: 10.1093/jn/nxy328

Sims, J. T., and Johnson, G. V. (1991). "Micronutrient soil tests," in Micronutrients in Agriculture, eds J. J. Mortvedt, F. R. Cox, L. M. Shuman, and R. M. Welch (Madison, WI: Soil Science Society America Book Series), 427-476. doi: 10. 2136/sssabookser4.2ed.c12

Skalny, A. V., Rink, L., Ajsuvakova, O. P., Aschner, M., Gritsenko, V. A., Alekseenko, S. I., et al. (2020). Zinc and respiratory tract infections: perspectives for COVID-19 (Review). Int. J. Mol. Med. 46, 17-26. doi: 10.3892/ijmm.2020. 4575

Smoleń, S., Kowalska, I., Czernicka, M., Halka, M., Kêska, K., and Sady, W. (2016). Iodine and selenium biofortification with additional application of salicylic acid affects yield, selected molecular parameters and chemical composition of lettuce plants (Lactuca sativa L. var. capitata). Front. Plant Sci. 7:1553. doi: $10.3389 /$ fpls.2016.01553
Smoleń, S., Kowalska, I., and Sady, W. (2014). Assessment of biofortification with iodine and selenium of lettuce cultivated in the NFT hydroponic system. Sci. Hortic. 166, 9-16. doi: 10.1016/j.scienta.2013.11.011

Sperotto, R., Ricachenevsky, F., Waldow, V., Muller, A., Dressler, V., and Fett, J. (2013). Rice grain $\mathrm{Fe}, \mathrm{Mn}$ and $\mathrm{Zn}$ accumulation: how important are flag leaves and seed number? Plant Soil Environ. 59:262. doi: 10.17221/841/2012-PSE

Steinbrenner, H., Al-Quraishy, S., Dkhil, M., Wunderlich, F., and Sies, H. (2015). Dietary selenium in adjuvant therapy of viral and bacterial infections. $A d v$. Nutr. 6, 73-82. doi: 10.3945/an.114.007575

Stomph, T. J., Jiang, W., and Struik, P. C. (2009). Zinc biofortification of cereals: rice differs from wheat and barley. Trends Plant Sci. 14, 123-124. doi: 10.1016/ j.tplants.2009.01.001

Tsukada, H., Takeda, A., Tagami, K., and Uchida, S. (2008). Uptake and distribution of iodine in rice plants. J. Environ. Qual. 37, 2243-2247. doi: 10.2134/jeq2008. 0010

Wang, J., Mao, H., Zhao, H., Huang, D., and Wang, Z. (2012). Different increases in maize and wheat grain zinc concentrations caused by soil and foliar applications of zinc in Loess Plateau. China. Field Crops Res. 135, 89-96. doi: 10.1016/j.fcr. 2012.07.010

Waters, B. M., Uauy, C., Dubcovsky, J., and Grusak, M. A. (2009). Wheat (Triticum aestivum) NAM proteins regulate the translocation of iron, zinc, and nitrogen compounds from vegetative tissues to grain. J. Exp. Bot. 60, 4263-4274. doi: $10.1093 /$ jxb/erp257

Wei, Y., Shohag, M. J. I., Yang, X., and Zhang, Y. (2012). Effects of foliar iron application on iron concentration in polished rice grain and its bioavailability. J. Agric. Food Chem. 60, 11433-11439. doi: 10.1021/jf3036462

Welch, R. M., Graham, R. D., and Cakmak, I. (2013). "Linking agricultural production practices to improving human nutrition and health, expert paper written for ICN2," in Second International Conference on Nutrition Preparatory Technical Meeting, 13-15 November, Rome, 2013.

Wissuwa, M., Ismail, A., and Graham, R. (2007). Rice grain zinc concentrations as affected by genotype, native soil-zinc availability, and zinc fertilization. Plant Soil 306, 37-48. doi: 10.1007/s11104-007-9368-4

Wu, T. Y., Gruissem, W., and Bhullar, N. K. (2019). Targeting intracellular transport combined with efficient uptake and storage significantly increases grain iron and zinc levels in rice. Plant Biotechnol. J. 17, 9-20. doi: 10.1111/ pbi. 12943

Yuan, L., Wu, L., Yang, C., and Lv, Q. (2013). Effects of iron and zinc foliar applications on rice plants and their grain accumulation and grain nutritional quality. J. Sci. Food Agric. 93, 254-261. doi: 10.1002/jsfa.5749

Zia, M. H., Watts, M. J., Gardner, A., and Chenery, S. R. (2015). Iodine status of soils, grain crops, and irrigation waters in Pakistan. Environ. Earth Sci. 73, 7995-8008. doi: 10.1007/s12665-014-3952-8

Zimmermann, M., and Andersson, M. (2012). Update on iodine status worldwide. Curr. Opin. Endocrinol. Diabetes Obes. 19, 382-387. doi: 10.1097/MED. 0b013e328357271a

Zou, C. Q., Du, Y. F., Rashid, A., Ram, H., Savasli, E., Pieterse, P., et al. (2019). Simultaneous biofortification of wheat with zinc, iodine, selenium, and iron through foliar treatment of a micronutrient cocktail in six countries. J. Agric. Food Chem. 67, 8096-8106. doi: 10.1021/acs.jafc.9b01829

Zou, C. Q., Zhang, Y. Q., Rashid, A., Ram, H., Savasli, E., Arisoy, R. Z., et al. (2012). Biofortification of wheat with zinc through zinc fertilization in seven countries. Plant Soil 361, 119-130. doi: 10.1007/s11104-012-1369-2

Conflict of Interest: The authors declare that the research was conducted in the absence of any commercial or financial relationships that could be construed as a potential conflict of interest.

Copyright (c) 2020 Prom-u-thai, Rashid, Ram, Zou, Guilherme, Corguinha, Guo, Kaur, Naeem, Yamuangmorn, Ashraf, Sohu, Zhang, Martins, Jumrus, Tutus, Yazici and Cakmak. This is an open-access article distributed under the terms of the Creative Commons Attribution License (CC BY). The use, distribution or reproduction in other forums is permitted, provided the original author(s) and the copyright owner(s) are credited and that the original publication in this journal is cited, in accordance with accepted academic practice. No use, distribution or reproduction is permitted which does not comply with these terms. 